\title{
Pengembangan modul digital untuk bahan ajar pengolahan citra di Jurusan Teknik Elektro Universitas Negeri Malang
}

\author{
Muhamad Luqmanul Hakim, Heru Wahyu Herwanto *, Gres Dyah Kusuma Ningrum \\ Universitas Negeri Malang, Jl. Semarang No. 5 Malang, Jawa Timur, Indonesia \\ *Penulis korespondensi, Surel: heru_wh@um.ac.id
}

Paper received: 03-01-2021; revised: 15-01-2021; accepted: 30-01-2021

\begin{abstract}
Abstrak
Perkembangan TIK dalam dunia pendidikan, pada akhirnya mendorong pendidik dan praktisi pendidikan untuk terus meningkatkan kualitas pendidikan. Seperti halnya upaya peningkatan dalam kualitas proses pembelajaran. Salah satu contoh dari upaya ini adalah dengan penggunaan metode yang tepat dan didukung dengan adanya pemanfaatan media dan bahan ajar yang berbentuk elektronik dalam pembelajaran. Salah satu bentuk bahan ajar yang dapat diterapkan dalam bentuk elektronik adalah modul digital berbasis epub. Tujuan penelitian ini adalah: merancang dan mengembangkan modul digital untuk bahan ajar Pengolahan Citra di Jurusan Teknik Elektro Universitas Negeri Malang dan menguji kelayan modul digital untuk bahan ajar Pengolahan Citra di Jurusan Teknik Elektro Universitas Negeri Malang. Penelitian pengembangan ini mengacu pada prosedur penelitian pengembangan menurut Sugiyono, yang dibatasi pada beberapa tahap saja. Tahap-tahap tersebut meliputi: a) potensi dan masalah, b) pengumpulan data, c) desain produk, d) validasi desain e) uji coba pemakaian. Modul digital untuk bahan ajar pengolahan citra divalidasi oleh ahli materi dan ahli media. Pada penilaian ahli materi dengan skor yang diperoleh adalah $87,5 \%$ kategori kriteria sangat valid. Penilaian yang dilakukan oleh ahli media dengan skor yang diperoleh adalah 79\% kategori kriteria cukup valid. Setelah divalidasi, modul digital tersebut diuji cobakan kepada 30 mahasiswa dengan memperoleh skor 87,9\% masuk kategori sangat valid. Modul digital pengolahan citra yang dikembangkan pada penelitian ini cukup valid dan layak digunakan sebagai modul pembelajaran dengan nilai rata-rata kelayakan adalah 84,7\%.
\end{abstract}

Kata kunci: pengembangan; modul digital; pengolahan citra

\section{Pendahuluan}

Lembaga Pendidikan Tenaga Kependidikan (LPTK) merupakan lembaga yang menghasilkan tenaga pendidik (guru) dan tenaga kependidikan. Sebagai lembaga penghasil guru, peranan LPTK sangat menentukan dalam meningkatkan kualitas pendidikan, karena guru merupakan aktor penting yang berperan dalam meningkatkan Pendidikan (Juhji, 2016). Program Studi S1 Teknik Informatika jurusan Teknik Elektro Universitas Negeri Malang merupakan salah satu LPTK yang ada di Indonesia.

Pendidikan merupakan salah satu vitalitas dalam kehidupan untuk memperbaiki, membangun dan merubah perilaku individu menjadi terarah dan lebih baik. Pendidikan bisa diterapkan melalui proses pembelajaran. Pendidikan mempunyai peran penting dan sangat besar dalam rangka menciptakan sumber daya manusia yang berkualitas untuk mengolah sumber daya alam yang ada guna mempertahankan kelangsungan hidup serta meningkatkan kemakmuran dan kesejahteraan rakyat. Pendidikan merupakan salah satu aspek kehidupan yang harus dan pasti dijalani oleh semua manusia sejak lahir, selama masa pertumbuhan dan berkembang sampai mencapai kematian. Dalam dunia pendidikan, banyak metode pembelajaran yang digunakan, dan itu akan terasa menyenangkan terkadang juga terasa membosankan.

Belajar merupakan kebutuhan pokok setiap manusia. Selain untuk memenuhi kebutuhan dalam memperoleh ilmu pengetahuan, belajar bertujuan untuk memenuhi kebutuhan dalam memperoleh perubahan perilaku. Proses belajar ini dapat dikelola dalam 
beberapa cara, salah satunya adalah dengan proses pembelajaran. Pembelajaran adalah proses untuk membantu peserta didik agar dapat belajar dengan baik. Kegiatan pembelajaran di dalam dunia perkuliahan dilakukan oleh dua orang pelaku, yaitu dosen dan mahasiswa. Perilaku dosen adalah mengajar dan perilaku mahasiswa adalah belajar. Pembelajaran dapat dilakukan secara klasikal di dalam kelas maupun disertai dengan berbagai strategi, pendekatan, dan metode pembelajaran yang beragam.

Salah satu komponen yang tidak dapat dipisahkan dalam proses pembelajaran adalah bahan ajar bisa berupa modul. Ketersediaan bahan ajar dapat menjadi salah satu penunjang keberhasilan pelaksanaan proses pembelajaran (Puspita \& Purwo, 2019). Bahan ajar berisikan susunan seperangkat materi untuk menciptakan lingkungan/suasana yang memungkinkan mahasiswa untuk belajar. Dengan demikian, salah satu tujuan penyediaan bahan ajar adalah untuk mempermudah proses belajar mahasiswa (Irma, dkk., 2019). Hubungan antara dosen, mahasiswa, dan bahan ajar bersifat dinamis dan kompleks.

Modul merupakan suatu jenis bahan ajar yang dirancang untuk dapat dipelajari secara mandiri oleh peserta didik dan dirancang secara sitematis dan menarik untuk mempermudah dalam proses pembelajaran. Sedangkan, modul digital merupakan sebuah bahan ajar yang dapat dibaca melalui komputer atau digital lainnya. Modul digital merupakan publikasi berupa teks dan gambar dalam bentuk digital yang diproduksi, diterbitkan, dan dapat dibaca melalui komputer atau digital lainnya (Andina, 2011). Modul digital mempunyai kelebihan yakni bentuk fisiknya berupa data digital dan dapat disimpan di media penyimpanan elektronik (Puspitasari, 2019). Modul digital memberikan dampak yang luar biasa pada kemajuan teknologi dalam Pendidikan (Hutahaean, dkk., 2019).

Bahan ajar merupakan bahan-bahan atau materi pelajaran yang disusun secara sistematis, yang digunakan guru dan peserta didik dalam proses pembelajaran. Bahan ajar dapat membantu dosen dalam melaksanakan kegiatan belajar mengajar di kelas. Oleh karena itu, dosen harus dapat memilih bahan ajar yang sesuai untuk diterapkan dalam proses belajar mengajar untuk mempermudah mahasiswa dalam memahami materi pembelajaran, sehingga dapat mencapai tujuan yang diharapkan yang sesuai dengan katalog Prodi Teknik Informatika Jurusan Teknik Eletro Universitas Negeri Malang. Pemilihan bahan ajar harus disesuaikan kepada kurikulum pembelajaran yang diterapkannya.

Pada umumnya dalam kegiatan pembelajaran dosen hanya menggunakan bahan ajar cetak, seperti buku pelajaran dan modul. Namun juga sudah ada yang menggunakan e modul berupa .pdf. Di dalam kelas dosen atau asisten dosen menerangkannya dengan power point. Tidak jarang mahasiswa mendapatkan tugas dari dosen, dan masih banyak mahasiswa kekurangan sumber belajar untuk mengerjakan tugas yang diberikan. Buku pelajaran sudah menjadi bahan ajar pokok dalam pembelajaran, sedangkan modul masih sangat jarang dimanfaatkan. Padahal, modul merupakan salah satu bahan ajar yang sangat menunjang proses belajar mahasiswa secara mandiri.

Modul dirancang secara sistematis dan berdasarkan kurikulum yang berlaku, seperti halnya untuk prodi Teknik Informatika Jurusan Teknik Eletro Universitas Negeri Malang menggunakan kurikulum 2019 yang sehingga dapat mencapai kompetensi yang diharapkan. Dengan modul, mahasiswa dapat belajar sendiri atau berkelompok yang berpedoman kepada modul tersebut sehingga ketuntasan belajar mahasiswa dapat dilihat dari ketercapaiannya dalam mempelajari materi yang ada di modul. Akan tetapi, mengingat perkembangan Ilmu Pengetahuan dan Teknologi (IPTEK) dewasa ini menuntut setiap orang dalam hal ini khususnya tenaga pendidik harus dapat berintekrasi dengan teknologi. Dengan masuknya 
IPTEK sekarang ini, setiap aktivitas manusia rata-rata di dominasi oleh teknologi. Oleh sebab perlunya berpikir kreatif dan tanggap terhadap perubahan tersebut.

Mata kuliah Pengolahan Citra menyajikan konsep persepsi visual, citra digital keabuan dan citra berwarna serta citra biner, teknik perbaikan dan restorasi citra, transformasi diskrit fourier dan wavelet, transformasi Hough, zooming. Standart capaian mata kuliah ini adalah Mahasiswa memiliki pengetahuan, pemahamanan dan ketrampilan tentang proses pengolahan citra digital beserta implementasinya. (Buku pedoman akademik - Program studi teknik informatika - tahun akademik 2019/2020).

Perkembangan TIK dalam dunia pendidikan, pada akhirnya mendorong pendidik dan praktisi pendidikan untuk terus meningkatkan kualitas pendidikan yang di dalamnya termasuk juga upaya peningkatan dalam kualitas proses pembelajaran. Salah satu contoh dari upaya ini adalah dengan penggunaan metode yang tepat dan didukung dengan adanya pemanfaatan media dan bahan ajar yang berbentuk elektronik dalam pembelajaran.

Salah satu bentuk bahan ajar yang dapat diterapkan dalam bentuk elektronik adalah modul digital. Modul selama ini kebanyakan hanya disajikan dalam bentuk cetak dan format pdf. Oleh karena itu, untuk dapat mengikuti perkembangan TIK dalam dunia pendidikan, maka dapat dikembangkan modul digital sebagai salah satu alternatif bahan ajar yang menarik. Modul digital ini berisikan paket program pembelajaran yang disajikan dalam bentuk epub, disusun dalam bentuk satuan tertentu guna keperluan belajar atau proses pembelajaran. Modul digital dalam bentuk epub ini berisikan materi pembelajaran disertai latihan soal yang menunjang materi pembelajaran.

Electronic publication (EPub) merupakan salah satu format buku digital yang disepakati oleh International Digital Publishing Forum (IDPF) pada Oktober 2011. EPub menggantikan peran Open eBook sebagai format buku terbuka. Epub terdiri atas file multimedia, html5, css, xhtml, xml yang dikemas dalam satu file. EPUB merupakan salah satu format untuk aplikasi ebook yang bersifat terbuka. Epub berfungsi untuk menunjang proses pembelajaran baik di sekolah maupun di perguruan tinggi. Kelebihan dari EPUB adalah memiliki ukuran yang dinamis, dapat memasukkan gambar, suara, maupun video, dilengkapi dengan daftar isi sehingga akses membacanya lebih mudah.

\section{Metode}

Jenis penelitian yang digunakan dalam penelitian ini adalah Research and Development (RnD). Penelitian dan pengembangan merupakan suatu proses atau langkah-langkah untuk mengembangkan suatu produk baru atau menyempurnakan produk yang telah ada dan dapat dipertanggung jawabkan. Model pengembangan modul ajar digital yang digunakan dalam penelitian ini menggunakan model pengembangan Sugiyono. Metode penelitian dan pengembangan juga didefinisikan sebagai suatu metode penelitian yang digunakan untuk menghasilkan produk tertentu, dan menguji keefektifan produk tersebut (Sugiyono, 2013). Penelitian pengembangan ini terbatas pada suatu proses pengembangan dan hanya memvalidasi produk-produk yang digunakan dalam pendidikan (Setyosari, 2012). Peneliti menggunakan model pengembangan Sugiyono karena langkah - langkah dalam model pengembangan sesuai dengan tujuan yang dihasilkannya produk bahan ajar untuk menguji kelayakan modul yang dihasilkan dan terdapat pemisahan langkah antara potensi masalah dan pengumpulan data sehingga proses pengembangan produk pada tahapan desain produk menjadi lebih stabil. Langkah-langkah yang harus diikuti untuk menghasilkan produk meliputi tahap potensi dan masalah, pengumpulan data, desain produk, validasi desain, revisi desain produk, uji coba produk, revisi produk, uji coba pemakaian, revisi produk, dan produksi masal. 
Ada beberapa prosedur pengembangan yang dikemukakan oleh beberapa ahli. Pada penelitian pengembangan ini mengacu pada prosedur penelitian pengembangan menurut Sugiyono yang disesuaikan dengan kebutuhan peneliti. Prosedur penelitian pengembangan menurut Sugiyono adalah seperti Gambar 1.

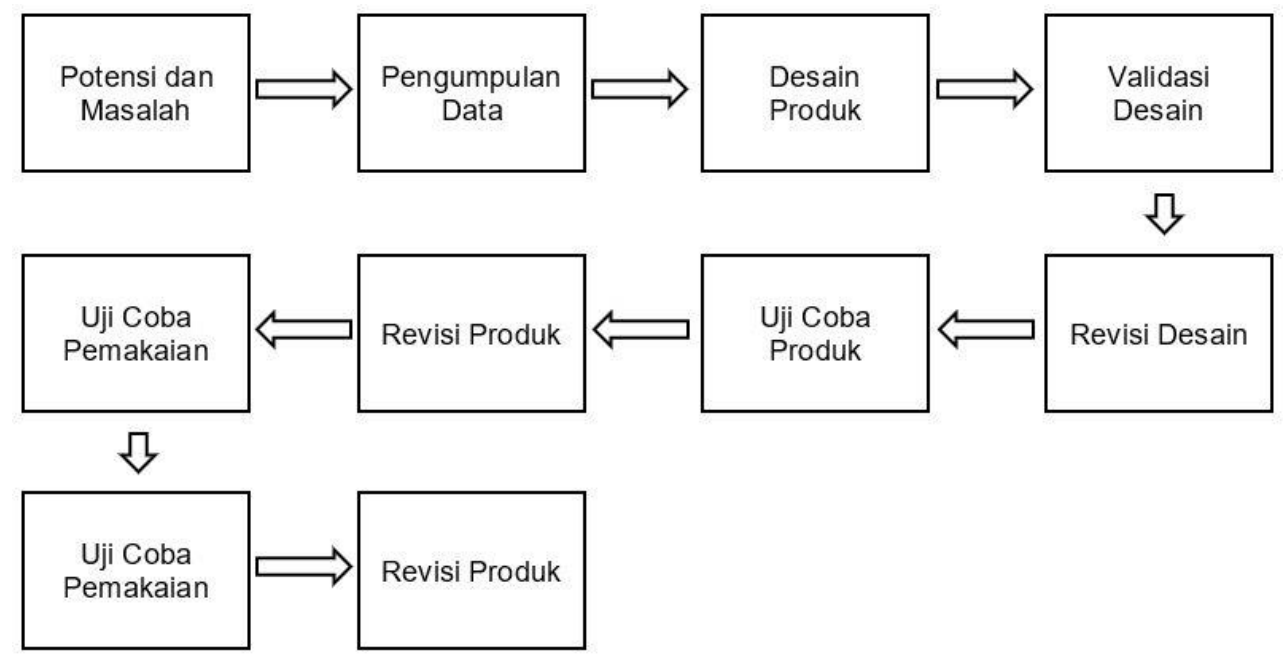

Gambar 1. Prosedur Penelitian Pengembangan

Penelitian pengembangan ini dibatasi pada beberapa tahap saja. Tahap-tahap tersebut meliputi a) tahap potensi dan masalah, b) pengumpulan data, c) desain produk, d) validasi desain, d) revisi desain produk. Validator dalam penelitian ini adalah ahli materi Pengolahan Citra dan ahli media pembelajaran. Mahasiswa merupakan subjek dalam penelitian ini, karena pelaksanaan uji penggunaan media dilakukan dalam pembelajaran matakuliah Pengolahan Citra, sehingga mahasiswa mempunyai kontribusi penting dalam merespon penggunaan modul digital untuk bahan ajar Pengolahan Citra di jurusan Teknik Elektro Universitas Negeri Malang.

1. Ahli materi, yaitu dosen pengampu matakuliah Pengolahan Citra di jurusan Teknik Elektro Universitas Negeri Malang

2. Ahli media, yaitu dosen Pendidikan Teknik Informatika yang mempunyai keahlian tentang media pembelajaran

3. Subjek penelitian modul digital ini adalah mahasiswa Prodi S1 Pendidikan Teknik Informatika tahun 2017 yang menempuh Matakuliah Pengolahan Citra.

4. Sesuai dengan tujuan penelitian pengembangan ini, maka data yang diperoleh adalah :

5. Data mengenai proses perancangan dan pengembangan modul digital untuk bahan ajar Pengolahan Citra.

6. Data tentang kelayakan modul digital untuk bahan ajar Pengolahan Citra sesuai dengan hasil uji penggunaan oleh ahli materi dan ahli media serta uji coba pemakaian oleh responden.

Data kuantitatif yaitu data yang berbentuk angka-angka dan data kualitatif yang dinyatakan dalam kata-kata atau simbol (Arikunto, 2013). Oleh sebab itu , data kuantitatif berupa hasil skor dari angket penilaian yang diisi oleh ahli materi, ahli media, dan responden (mahasiswa). Sedangkan data kualitatif berupa tanggapan dan saran ahli materi, ahli media dan responden (mahasiswa) yang berupa kritikan maupun saran tentang perbaikan modul yang akan dikembangkan. Jenis data dan pengumpulan data dapat dilihat pada Tabel 1. 
Tabel 1. Jenis Data dan Instrumen Pengumpulan Data

\begin{tabular}{llll}
\hline \multirow{2}{*}{ No } & Jenis Data & & Instrumen Pengumpulan Data \\
\cline { 2 - 3 } & Kuantitatif & Kualitatif & \\
\hline 1 & $\sqrt{ }$ & $\sqrt{ }$ & Angket \\
2 & $\sqrt{ }$ & $\sqrt{ }$ & Angket \\
3 & $\sqrt{ }$ & $\sqrt{ }$ & Angket \\
\hline
\end{tabular}

Penyusunan Instrumen pada penelitian ini instrumen yang digunakan adalah lembar penilaian kelayakan berupa angket. Angket adalah sejumlah pertanyaan tertulis yang digunakan untuk memperoleh informasi dari responden dalam arti laporan tentang pribadinya, atau hal-hal yang ia ketahui (Arikunto, 2013). Di bagian awal angket berbentuk Cheklist yang dipisahkan oleh beberapa skala yang dinamakan skala Likert $(4,3,2,1)$ Kisi-kisi tabel kriteria skala Likert dapat dilihat pada Tabel 2.

Tabel 2. Skala Likert

\begin{tabular}{ll}
\hline Skala & Keterangan \\
\hline 1 & Tidak Baik / Tidak layak \\
2 & Kurang Baik / Kurang Layak \\
3 & Baik / Layak \\
4 & Sangat Baik / Sangat Layak \\
\hline
\end{tabular}

Untuk melakukan penilaian, validator memberikan tanda check $(\sqrt{ })$ pada kolom yang dipilih berdasarkan pendapat mereka, sedangkan untuk kritik dan saran, peneliti menyediakan sebuah bagian yang kosong di lembar terakhir. Angket yang dapat digunakan validator untuk memberikan kritik dan saran terhadap bahan ajar yang diuji. Penelitian ini menggunakan analisis deskriptif yang sesuai dengan prosedur pengembangan yang dilakukan. Data yang diperoleh dari skor angket kemudian dianalisa dengan menggunakan teknik data presentase. Analisis yang digunakan dalam penelitian ini adalah berbentuk kuantitatif. Langkah-langkah analisis data yang dilakukan salah satunya adalah mengubah penilaian dalam bentuk kualitatif menjadi kuantitatif dengan ketentuan sebagai berikut. Angket yang diberikan dalam penelitian pengembangan ini menggunakan rating scale dengan 4 (empat) kategori. Kriteria skala Likert masing-masing kategori skala penilaian ditunjukkan pada Tabel 3.

Tabel 3. Skala Likert dari Masing Masing Kategori Skala Penilaian.

\begin{tabular}{ll}
\hline Skor & Kategori \\
\hline 4 & Sangat baik/sangat menarik/sangat jelas/sangat sesuai/sangat tepat/sangat layak \\
3 & Baik/menarik/jelas/sesuai/tepat/layak \\
2 & Kurang baik/kurang menarik/kurang jelas/kurang sesuai/kurang tepat/kurang layak \\
1 & Tidak baik/tidak menarik/tidak sesuai/tidak tepat/tidak layak \\
\hline
\end{tabular}

Kemudian analisa data untuk angket ahli media, ahli materi, dan responden (mahasiswa), nilai validitas dapat dihitung dengan persamaan 3.1 (Akbar, 2013).

$$
V A=\frac{\mathrm{TSe}}{\mathrm{TSh}} \times 100 \%
$$

Keterangan:

VA = Validitas 
TSe $\quad=$ Total skor empirik hasil validasi

TSh = Total skor maksimum hasil validasi

$100 \%=$ Konstanta

Data yang telah diperoleh dari skor angket kemudian dianalisis dengan menggunakan teknik analisis validitas deskriptif (Akbar, 2013). Perolehan persentase perhitungan nilai angket akan dianalisa sesuai dengan kriteria yang dituliskan pada Tabel 4.

Tabel 4. Kriteria kelayakan

\begin{tabular}{ll}
\hline $\begin{array}{l}\text { Tingkat } \\
\text { Persentase }\end{array}$ & Tingkat Validitas \\
\hline $\begin{array}{l}85,01 \%-100,00 \\
\%\end{array}$ & Sangat valid, atau dapat digunakan tanpa revisi \\
$70,01 \%-85,00 \%$ & $\begin{array}{l}\text { Cukup valid, atau dapat dilakukan namun perlu sedikit revisi } \\
\text { Ko,01\%-70,00\% } \\
\text { Kang valid, atau disarankan tidak digunakan karena perlu adanya revisi } \\
\text { yang besar } \\
\text { Tidak valid, atau tidak boleh digunakan }\end{array}$ \\
\hline & \multicolumn{1}{c}{ Sumber: Akbar (2017)..}
\end{tabular}

\section{Hasil dan Pembahasan}

Tabel 5. Hasil Penilaian oleh Ahli Materi

\begin{tabular}{llllll}
\hline No & Aspek Penilaian & TSe & TSh & Skor (\%) & Kategori \\
\hline 1 & Desain Pembelajaran & 14 & 16 & $87,5 \%$ & Sangat Valid \\
2 & Kelayakan Isi & 23 & 28 & $82,1 \%$ & Cukup Valid \\
3 & Ketepatan Cakupan Isi & 27 & 28 & $82,1 \%$ & Sangat Valid \\
4 & Penggunaan Bahasa & 6 & 8 & $75 \%$ & Cukup Valid \\
& Total & 70 & 80 & $87,5 \%$ & Sangat Valid \\
\hline
\end{tabular}

Keterangan:

$$
\text { Presentase kelayakan }(\%)=\frac{\text { Skor yang diperoleh }(\mathrm{TSe})}{\text { Skor yang diharapkan }(\mathrm{TSh})} \times 100 \%
$$

Penilaian modul untuk ahli materi terbagi menjadi 4 aspek. Hasil penilaian pada masingmasing aspek mendapatkan skor yang berbeda-beda. Pada aspek desain pembelajaran didapatkan skor sebesar 87,5\% yang berarti masuk dalam kategori "sangat valid". Pada aspek kelayakan isi didapatkan skor 82,1\%yang berarti masuk dalam kategori "cukup valid". Pada aspek ketepatan cakupan isi didapatkan skor 82,1\% yang berarti masuk dalam kategori "sangat valid". Pada aspek penggunaan bahasa didapatkan skor 75\% yang berarti masuk dalam kategori "cukup valid". Hasil penilaian ahli materi secara keseluruhan mendapatkan skor total sebesar $87,5 \%$ dari skor maksimal $100 \%$.

Tabel 6. Hasil Penilaian oleh Ahli Media

\begin{tabular}{llllll}
\hline No & Aspek Penilaian & TSe & TSh & Skor & Kategori \\
\hline 1 & Tampilan Tulisan & 21 & 24 & 87,5 & Sangat Valid \\
2 & Desain & 24 & 32 & $75 \%$ & Cukup Valid \\
3 & Format & 9 & 12 & $75 \%$ & Cukup Valid \\
& Total & 54 & 68 & $79 \%$ & Cukup Valid \\
\hline
\end{tabular}

Keterangan: 


$$
\text { Presentase kelayakan }(\%)=\frac{\text { Skor yang diperoleh }(\mathrm{TSe})}{\text { Skor yang diharapkan }(\mathrm{TSh})} \times 100 \%
$$

Penilaian untuk ahli media terbagi menjadi 3 aspek. Hasil penilaian pada masing-masing aspek mendapatkan skor yang berbeda-beda. Pada aspek desain pembelajaran skor sebesar 87,5\% yang berarti masuk dalam kategori "sangat valid". Pada aspek kelayakan isi didapatkan skor $75 \%$ yang berarti masuk dalam kategori "cukup valid". Pada aspek penggunaan bahasa didapatkan skor 75\% yang berarti masuk dalam kategori "cukup valid". Hasil penilaian ahli materi secara keseluruhan mendapatkan skor total sebesar 79\% dari skor maksimal 100\%. Uji coba modul dilakukan dengan meminta tanggapan responden sejumlah 30 mahasiswa. Tujuan pengujian modul ini adalah untuk mendapatkan tanggapan responden seberapa layak modul digunakan. Data hasil penilaian uji coba modul dapat dilihat pada tabel 7.

Tabel 7. Hasil Uji Coba Modul

\begin{tabular}{llllll}
\hline No & Aspek Penilaian & TSe & TSh & Skor (\%) & Kategori \\
\hline 1 & Desain Pembelajaran & 315 & 360 & $87,5 \%$ & Sangat Valid \\
2 & Kelayakan Isi & 843 & 960 & $87,8 \%$ & Sangat Valid \\
3 & Keterbacaan modul & 318 & 360 & $88,3 \%$ & Sangat Valid \\
4 & Visualisasi Modul & 423 & 480 & $88,1 \%$ & Sangat Valid \\
& Total & 1899 & 2160 & $87,7 \%$ & Sangat Valid \\
\hline
\end{tabular}

Keterangan:

$$
\text { Presentase kelayakan }(\%)=\frac{\text { Skor yang diperoleh }(\mathrm{TSe})}{\text { Skor yang diharapkan }(\mathrm{TSh})} \times 100 \%
$$

Penilaian untuk uiji coba modul terbagi menjadi 4 aspek. Hasil penilaian pada masingmasing aspek mendapatkan skor yang berbeda-beda. Pada aspek desain pembelajaran skor sebesar $87,5 \%$ yang berarti masuk dalam kategori "sangat valid". Pada aspek kelayakan isi didapatkan skor $87,8 \%$ yang berarti masuk dalam kategori "sangat valid". Pada aspek keterbacaan modul didapatkan skor $88,3 \%$ yang berarti masuk dalam kategori "sangat valid". Pada aspek visualisasi modul didapatkan skor $88,1 \%$ yang berarti masuk dalam kategori "sangat valid". Hasil penilaian ahli materi secara keseluruhan mendapatkan skor total sebesar $87,7 \%$ dari skor maksimal $100 \%$.

Penelitian pengembangan ini mengacu pada prosedur penelitian pengembangan menurut Sugiyono, yang dibatasi pada beberapa tahap saja. Tahap-tahap tersebut meliputi; a) potensi dan masalah, b) pengumpulan data, c) desain produk, d) validasi desain e) uji coba produk. Proses pengembangan ini dilaksanakan dengan 4 tahap dan berdasarkan tujuan penelitian yaitu untuk mengembangkan modul dengan prosedur yang tepat. Alur pengembangan tersebut dianggap tepat dilakukan sebab dengan proses pengembangan tersebut dilakukan 3 tahapan utama yaitu proses pembuatan modul digital pengolahan citra, pengujian kelayakan modul modul digital pengolahan citra dan pengujian keefektifan modul digital pengolahan citra. Dengan proses pengembangan tersebut diharapkan modul layak dan efektif digunakan sebagai modul pembelajaran.

Modul digital untuk bahan ajar pengolahan citra telah di validasi oleh ahli materi dan ahli media. Pada penilaian ahli materi dengan skor yang diperoleh adalah 87,5\% kategori kriteria sangat valid. Penilaian yang dilakukan oleh ahli media dengan skor yang diperoleh adalah 79\% kategori kriteria cukup valid. Setelah divalidasi, modul digital tersebut di uji cobakan kepada 30 mahasiswa dengan memperoleh skor 87,9\% masuk kategori sangat valid. 
Modul digital pengolahan citra yang dikembangkan pada penelitian ini cukup valid dan layak digunakan sebagai modul pembelajaran dengan nilai rata-rata kelayakan adalah $84,7 \%$ dan masuk dalam kriteria cukup valid.

Kriteria cukup valid merupakan kriteria penilaian yang masuk dalam kategori dapat dilakukan namun perlu sedikit revisi. Kemudian dari langkah tersebut dilanjutkan dengan memperbaiki produk berdasarkan pendapat para ahli materi dan media dalam penyusunan modul.

\section{Simpulan}

Berdasarkan hasil penelitian dan pembahasan maka dapat ditarik kesimpulan bahwa proses Pengembangan modul digital untuk bahan ajar pengolahan citra mengacu pada pengembangan Sugiyono, yang dibatasi pada beberapa tahap saja. Tahap-tahap tersebut meliputi; a) potensi dan masalah, b) pengumpulan data, c) desain produk, d) validasi desain e) uji coba produk. Kemudian modul digital untuk bahan ajar pengolahan citra yang dikembangkan pada penelitian ini, termasuk pada kriteria cukup valid dan layak digunakan sebagai modul pembelajaran pada mata kuliah pengolahan citra di jurusan teknik elektro Universitas Negeri Malang..

\section{Daftar Rujukan}

Akbar, S. (2013). Instrumen Perangkat Pembelajaran. PT Remaja Rosdakarya.

Andina, E. (2011). Buku digital dan pengaturannya. Aspirasi: Jurnal Masalah-Masalah Sosial, 2(1), 79-95.

Arikunto, S. (2013). Prosedur Penelitian: Suatu Pendekatan Praktik. PT Rineka Cipta.

Hutahaean, L. A., Siswandari, \& Harini. (2019). Pemanfaatan E-Module Interaktif Sebagai Media Pembelajaran di Era Digital. Prosiding Seminar Nasional Teknologi Pendidikan Pascasarjana UNIMED, 298-305.

Irma, I., Arsyad, A., \& Bahraeni, B. (2019). Pengembangan bahan ajar teknologi pembelajaran berbasis webblog pada mahasiswa Fakultas Tarbiyah dan Keguruan Universitas Islam Negeri Alauddin Makassar. Inspiratif Pendidikan, 8(2), 271-280.

Juhji, J. (2016). Peran Urgen Guru dalam Pendidikan. Studia Didaktika, 10(1), 51-62.

Puspita, A. M. I., \& Purwo, S. (2019). Pengaruh Bahan Ajar Berbasis Literasi Dengan Pendekatan Kontekstual Terhadap Hasil Belajar Siswa Sekolah Dasar. Al-Aulad: Journal of Islamic Primary Education, 2(1).1-7

Puspitasari, A. D. (2019). Penerapan Media Pembelajaran Fisika Menggunakan Modul Cetak dan Modul Elektronik pada Siswa SMA. Jurnal Pendidikan Fisika, 7(1), 17-25.

Setyosari, P. (2010). Metode penelitian pendidikan dan pengembangan.

Sugiono, A. (2001). Metode penelitian pendidikan pendekatan kuantitatif. Kualitatif dan R\&D. Alfabeta. 